University of Wollongong

Research Online

Faculty of Science, Medicine and Health -

Papers: Part B

Faculty of Science, Medicine and Health

$1-1-2020$

\title{
New insights into the geological evolution of West Papua from recent field and laboratory studies
}

Lloyd T. White

University of Wollongong, Iloydw@uow.edu.au

Max Webb

University of Wollongong

Benjamin M. Jost

David Gold

Indra Gunawan

See next page for additional authors

Follow this and additional works at: https://ro.uow.edu.au/smhpapers1

\section{Publication Details Citation}

White, L. T., Webb, M., Jost, B. M., Gold, D., Gunawan, I., \& Tiranda, H. (2020). New insights into the geological evolution of West Papua from recent field and laboratory studies. Faculty of Science, Medicine and Health - Papers: Part B. Retrieved from https://ro.uow.edu.au/smhpapers1/1470 


\title{
New insights into the geological evolution of West Papua from recent field and laboratory studies
}

\author{
Abstract \\ Our understanding of the geological evolution of West Papua (or the Bird's Head Peninsula and Bird's \\ Neck) predominantly stems from a systematic mapping campaign conducted by Indonesian and \\ Australian geologists during the 1970's and 80's, together with the findings of mineral and hydrocarbon \\ exploration by Dutch geologists in the early 1900's. Most of the research that has been conducted since \\ these initial, but comprehensive studies have been associated with continued exploration for \\ hydrocarbons (e.g., around the Salawati and Bintuni Basins) and precious metals (e.g., associated with \\ Grasberg-Ertsburg). Here we present an overview of research conducted over the past five years that was \\ largely funded by several oil exploration companies. Our research did not focus on oil exploration, but \\ instead attempted to update our understanding of the age of magmatic, metamorphic and deformation \\ events, and to improve our knowledge of the regional stratigraphy of West Papua. These new data have \\ been used to develop new tectonic models and paleogeographic maps that provide a framework for \\ future studies in the region to build upon.

\section{Publication Details} \\ White, L. T., Webb, M., Jost, B. M., Gold, D., Gunawan, I. \& Tiranda, H. (2020). New insights into the \\ geological evolution of West Papua from recent field and laboratory studies. AIP Conference Proceedings, \\ 2245 (1), 070037-1-070037-8.
}

\section{Authors}

Lloyd T. White, Max Webb, Benjamin M. Jost, David Gold, Indra Gunawan, and Herwin Tiranda 


\section{New insights into the geological evolution of West Papua from recent field and laboratory studies}

Cite as: AIP Conference Proceedings 2245, 070037 (2020); https://doi.org/10.1063/5.0006819 Published Online: 08 July 2020

Lloyd T. White, Max Webb, Benjamin M. Jost, David Gold, Indra Gunawan, and Herwin Tiranda

ARTICLES YOU MAY BE INTERESTED IN

Critical success factor measurement model implementation of natural disaster mitigation knowledge management systems

AIP Conference Proceedings 2245, 020002 (2020); https://doi.org/10.1063/5.0006797

Vein textures at the Hill Reef Zone, the Poboya prospect, Central Sulawesi, Indonesia AIP Conference Proceedings 2245, 070029 (2020); https://doi.org/10.1063/5.0007050

Deepwater stimulation: A case study of frac pack modelling in well G1

AIP Conference Proceedings 2245, 070033 (2020); https://doi.org/10.1063/5.0006814

\section{Lock-in Amplifiers up to $600 \mathrm{MHz}$

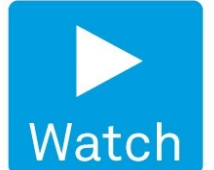

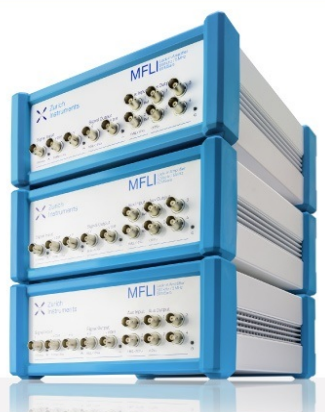




\title{
New Insights Into The Geological Evolution of West Papua From Recent Field and Laboratory Studies
}

\author{
Lloyd T. White ${ }^{1, \text { a) }}$, Max Webb ${ }^{1,2}$, Benjamin M. Jost ${ }^{2}$, David Gold ${ }^{3}$, Indra \\ Gunawan $^{4}$ and Herwin Tiranda ${ }^{4}$ \\ ${ }^{1}$ GeoQuEST Research Centre, School of Earth, Atmospheric and Life Sciences, Northfields Avenue, University of \\ Wollongong, 2522, Australia \\ ${ }^{2}$ Southeast Asia Research Group, Royal Holloway University of London, Egham, Surrey, UK, TW20 OEX. \\ ${ }^{3} C G G$ Robertson, Tynycoed, Llanrhos, Llandudno, United Kingdom \\ ${ }^{4}$ Institut Teknologi, Bandung, Jalan Ganesha 10 Bandung, Indonesia \\ a)Corresponding author: 1loydw@uow.edu.au
}

\begin{abstract}
Our understanding of the geological evolution of West Papua (or the Bird's Head Peninsula and Bird's Neck) predominantly stems from a systematic mapping campaign conducted by Indonesian and Australian geologists during the 1970's and 80's, together with the findings of mineral and hydrocarbon exploration by Dutch geologists in the early 1900's. Most of the research that has been conducted since these initial, but comprehensive studies have been associated with continued exploration for hydrocarbons (e.g., around the Salawati and Bintuni Basins) and precious metals (e.g., associated with Grasberg-Ertsburg). Here we present an overview of research conducted over the past five years that was largely funded by several oil exploration companies. Our research did not focus on oil exploration, but instead attempted to update our understanding of the age of magmatic, metamorphic and deformation events, and to improve our knowledge of the regional stratigraphy of West Papua. These new data have been used to develop new tectonic models and paleogeographic maps that provide a framework for future studies in the region to build upon.
\end{abstract}

\section{INTRODUCTION}

The province of West Papua, in eastern Indonesia encompasses the "Bird's Head Peninsula" and "Bird's Neck" region of the island of New Guinea (Figure 1). The region was first mapped by Dutch geologists before 1935, as well as during an oil exploration program conducted between 1935 and 1960 (Visser and Hermes 1962). More comprehensive geological mapping was jointly undertaken by Indonesian and Australian geologists during the late 1970 's and early 80 's and this work led to a series of 1:250,000 scale map sheets across western New Guinea, with their work being synthesized and discussed in several journal papers (e.g., Pieters et al., 1983; Dow et al., 1986; 1988). The joint Indo-Australian mapping campaign consisted of numerous field parties that established regional camps and utilized helicopters to access difficult to reach areas that were covered by dense tropical rainforest. Research of this scale will almost certainly never be achieved again without the support of Government together with substantial financial investment. However, exploration companies have been supporting various smaller-scale geological expeditions and research programs over the past decade, and this work, combined with new geophysical data has led to a growing body of data that is shedding new light on the tectonic history of this complicated region (e.g., Pairault et al., 2003; Bailly et al., 2009; Saputra et al., 2014). This work has benefited from ongoing development in West Papua, particularly through road construction which has opened up areas that were previously difficult to access as well as exposing rocks that were previously covered by dense tropical vegetation. Here we summarize some of our recent findings from West Papua. Most of this work has stemmed from field-based studies in addition to the collection of new isotopic, biostratigraphic, and geochemical data.

2nd International Conference on Earth Science, Mineral, and Energy

AIP Conf. Proc. 2245, 070037-1-070037-8; https://doi.org/10.1063/5.0006819

Published by AIP Publishing. 978-0-7354-2004-5/\$30.00 

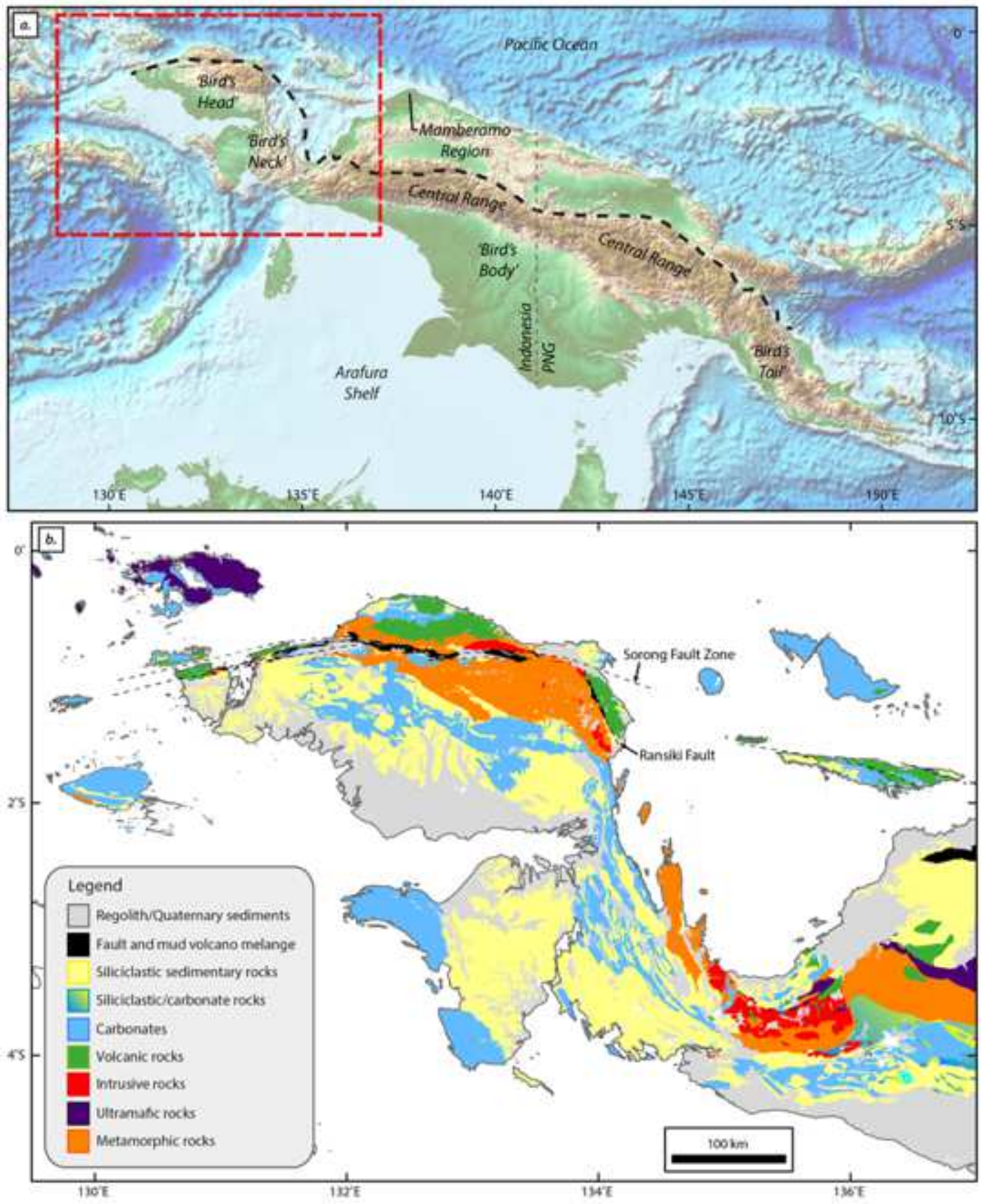

FIGURE 1. (A) Map of New Guinea showing the location of the Bird's Head Peninsula, Bird's Neck, Bird's Body, and Bird's Tail as well as other geographic features such as the Central Range and an approximate boundary marked with a dotted line showing the approximate and simplified extent of 'Australian' crust (to the south of the line) and crust with a Pacific affinity (north of the line). The work that is discussed here reports results from several recent studies conducted within the Bird's Head Peninsula and the north-eastern part of the Bird's Neck region. (B) Map showing the distribution of different lithologies of the Bird's Head and Bird's Neck regions of western New Guinea. These images were taken from Gold et al., (2017) and reprinted with permission from Elsevier using the Copyright Clearance Center RightsLink ${ }^{\circledR}$ service. 


\section{THE BIRDS HEAD PENINSULA}

The Bird's Head Peninsula contains Silurian through to Recent rocks, recording various events that occurred along the northern margin of Eastern Gondwana, and later, various events that occurred at the interface between the Australian, Pacific, and Philippine Sea Plates (e.g., Hamilton, 1979; Hill and Hall 2003). This long history of tectonism has driven various episodes of magmatism, metamorphism, and deformation, tectonically juxtaposing rocks of different age and composition against one another. As such, New Guinea can broadly be differentiated into at least three terranes (e.g., Pieters et al., 1983). These include: (1) continental crust broadly found along, and south of New Guinea's Central Range and the highlands of the Bird's Head Peninsula - these rocks include Paleozoic metasedimentary sequences and granitoids that likely developed as part of the same tectonic systems that are found in eastern and northern Australia, as well as a Mesozoic carbonate platform and siliciclastic sequences; (2) volcanic rocks that are located along the northern margin of New Guinea that were derived from volcanic arcs and ocean floor that were obducted onto the northern margin of New Guinea during the Cenozoic, and (3) a 'transition zone' consisting of deformed and metamorphosed rocks that developed due to Cenozoic tectonism. However, readers should note that this definition is simplistic and does not capture the true complexity of the region.

We have spent the past five years focusing our efforts to better understand this complicated tectonic history, yet we also acknowledge that there is still much to do. This paper presents an overview of our recent work on different aspects of the Bird's Head Peninsula and surrounding region.

\section{NEW BIOSTRATIGRAPHIC DATA AND PALEOGEOGRAPHIC MAPS}

A regional synthesis of biostratigraphic data was conducted on 136 public domain exploration wells across western New Guinea and combined with paleontological data obtained from 200 outcrop samples that were collected by the authors between 2012-2016, together with additional fossil localities from existing research reports (Gold et al., 2017). All of the data were incorporated into a large spatial database and examined further within a geographic information system. We assigned paleodepositional environment attributes to each biostratigraphic data entry within the database and used this information, together with existing geological maps to create a series of simplified paleogeographic maps of Western New Guinea from the Carboniferous to the present day (Gold et al., 2017; e.g., Figure 2). These maps do not incorporate deformation or movement of tectonic plates, but we expect to complete this work in due course.

We also used the known bathyal preferences of fossils to generate a regional sea-level curve that we compared with global sea level curves to determine episodes of uplift and relative sea level change (Figure 3). This work identified major transgressive-regressive cycles in regional relative sea-level, with the highest sea levels occurring during the Late Cretaceous and Late Miocene. The biostratigraphic data and their interpreted paleodepositional environments highlight first order changes in the paleogeographic evolution of Western New Guinea. This includes evidence for: (1) terrestrial deposition across much of the region during the Late Paleozoic and Early Miocene; (2) a regional transgressive event during the Late Jurassic and Late Cretaceous, and; (3) lower sea-levels during regressions between the Late Cretaceous and the Paleogene (which resulted in widespread shallow water carbonate platform development in the Middle to Late Eocene. The paleographic data and comparison of the relative sea-level curve with global sea level curves also highlights episodes of tectonic uplift. For instance, uplift during the Early Miocene is marked by a regional unconformity, which was interpreted to mark the collision of intra-oceanic volcanic arcs (Gold et al., 2017). 

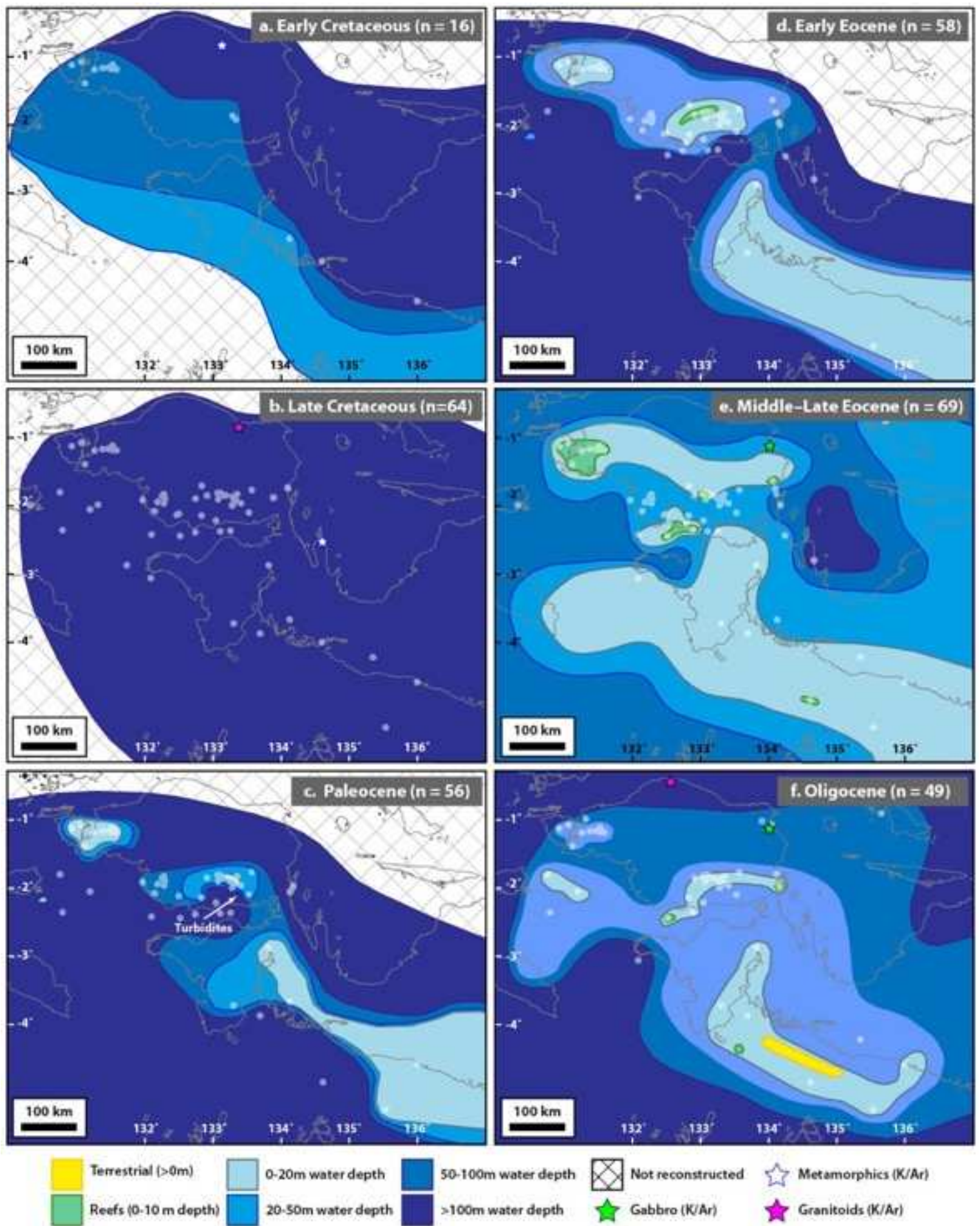

50-100m water depth $>100 \mathrm{~m}$ water depth

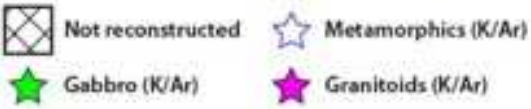

FIGURE 2. An example of the paleogeographic maps that were developed by Gold et al., (2017) for western New Guinea. The white dots indicate the location of sample points or exploration wells that were used to infer the age of particular rocks and their paleodepositional settings. Image taken from Gold et al., (2017) with permission from Elsevier using the Copyright Clearance Center RightsLink ${ }^{\circledR}$ service. 


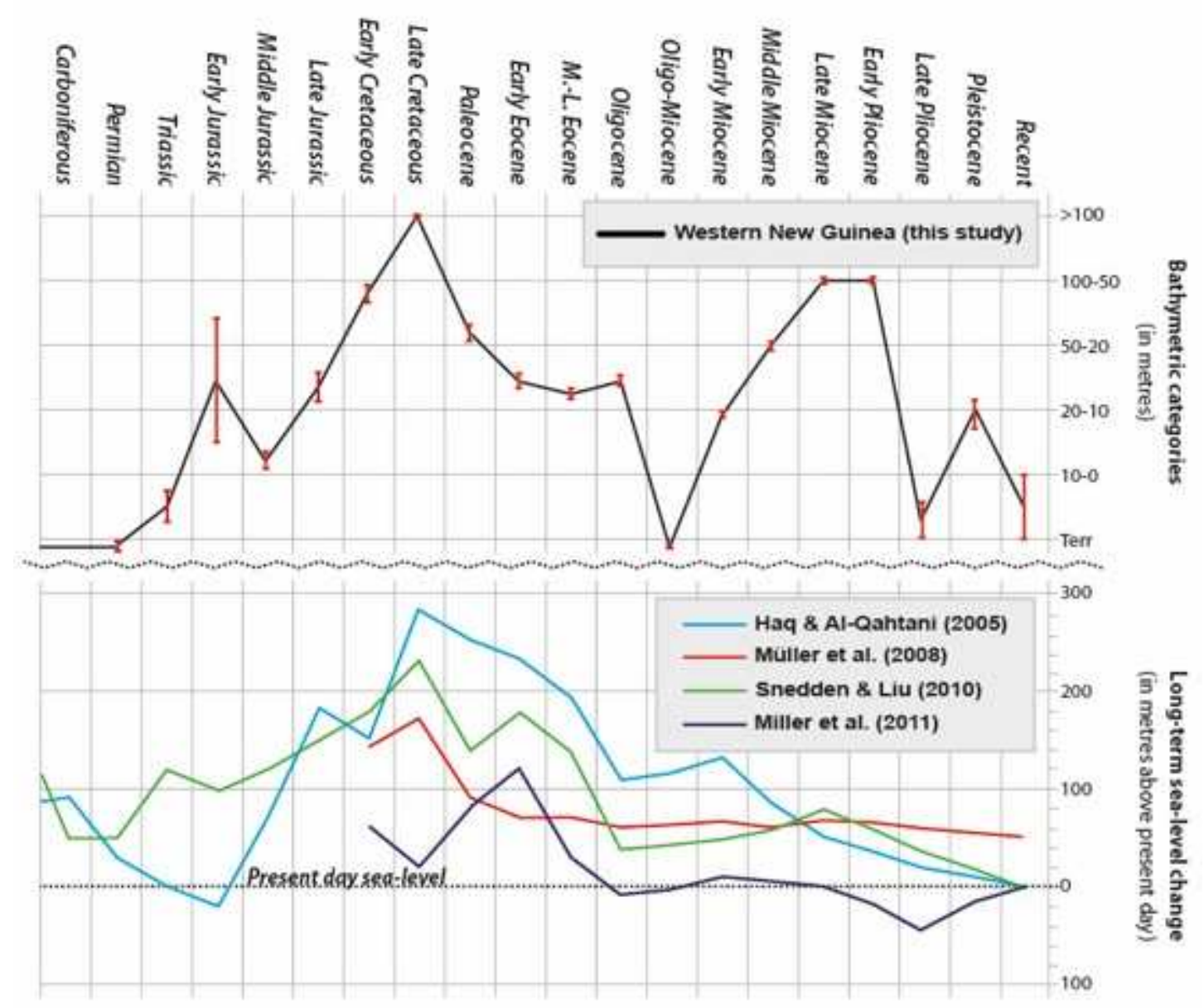

FIGURE 3. Gold et al., (2017) produced a regional, relative sea-level curve for Western New Guinea using biostratigraphic data and an interpretation of paleodepositional conditions. This regional curve can be compared with global sea level curves produced by Haq and Al-Qahtani (2005); Muller et al., (2008); Snedden and Liu (2010) and Miller et al. (2011) to reveal cycles of transgressions and regressions as well as tectonically driven uplift and subsidence. The error bars $=$ standard error of the mean. Image taken from Gold et al., (2017) with permission from Elsevier using the Copyright Clearance Center RightsLink ${ }^{\circledR}$ service.

\section{DEVONIAN TO TRIASSIC MAGMATISM}

Much of the mountainous region of the Bird's Head Peninsula is part of an inlier where Paleozoic and Mesozoic basement has been exposed. This basement high consists of Paleozoic metasedimentary rocks that were intruded by Paleozoic and Mesozoic granitoids. These rocks had been discussed in previous work on the area, but our knowledge of the timing of magmatism was quite limited, and relied on a series of $\mathrm{K}$-Ar ages that were reported in the grey-literature (e.g., Bladon 1988). We conducted a comprehensive study of the granitoids exposed throughout the Bird's Head and Bird's Neck regions. This work consisted of comprehensive descriptions of the field relations, petrography and bulk-rock geochemistry, as well as U-Pb zircon age data (Webb and White, 2016; Decker et al., 2017; Jost et al., 2018). We found that most of the granitoids exposed across western New Guinea were emplaced as small to medium-scale intrusions during two episodes, the first occurred during the Devonian-Carboniferous and this was followed by a second phase of magmatism during the Late Permian-Triassic, but separated by an apparent period of magmatic quiescence (Jost et al., 2018). The first phase of magmatism went unrecognized prior to this study - we assume because the episode of Late Permian-Triassic magmatism reset the K-Ar system within the oldest rocks, meaning that these rocks yielded Late Permian-Triassic ages in earlier studies that used the $\mathrm{K}-\mathrm{Ar}$ technique. The Paleozoic and Mesozoic granitoids are predominantly peraluminous and derived from partial melting 
of the country rock. The Devonian-Carboniferous granitoids are only found in a relatively small area, whereas the Permian-Triassic intrusions are found across the Bird's Head, Bird's Neck, and throughout other parts of New Guinea. The data suggest that these formed as part of an extensive active continental margin above a subduction system that extended along the length of New Guinea and potentially continued southward through eastern Australia and Antarctica (Figure 4).

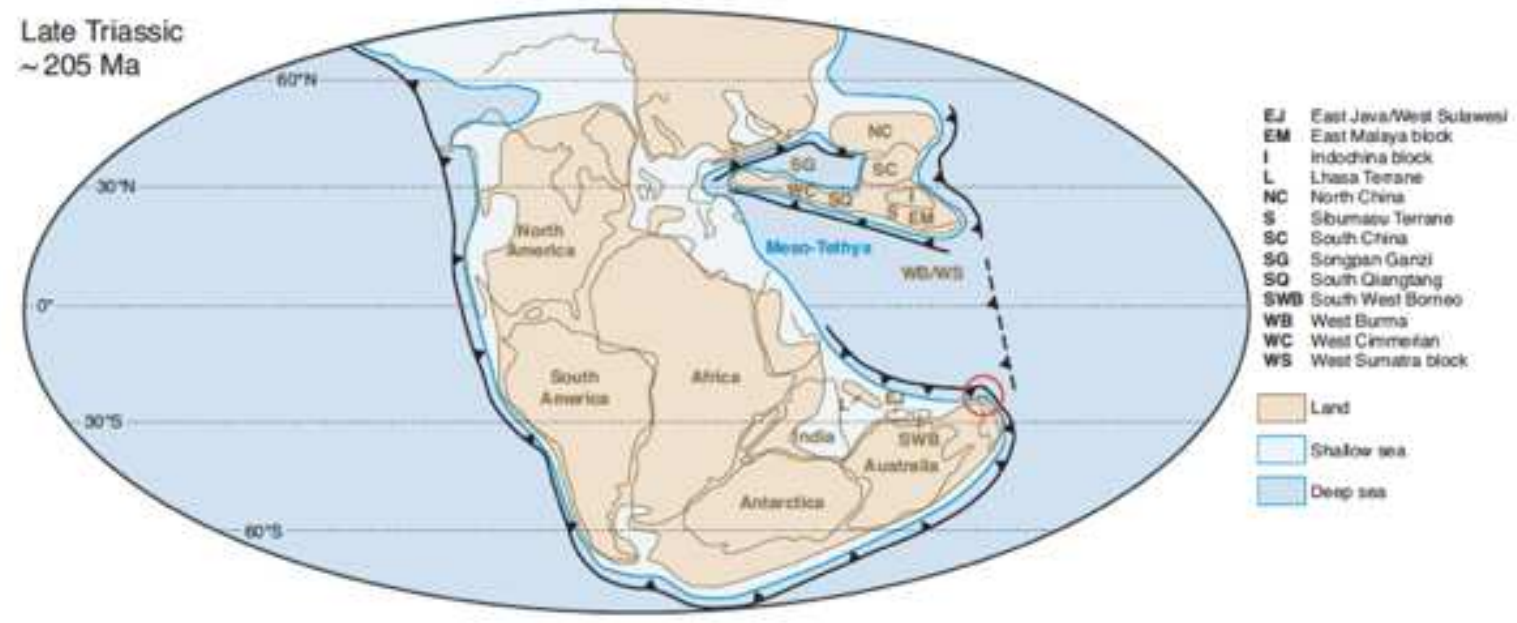

FIGURE 4. The Permo-Triassic granitoids that are found within the Bird's Head Peninsula and Bird's Neck region (red circle) likely formed above an active subduction system that extended along the length of New Guinea and southward along what is now the east coast of Australia as well as Antarctica. This reconstruction was presented by Jost et al., (2018) and was modified from Metcalfe (2013). Image taken from Jost et al., (2017) with permission from Elsevier using the Copyright Clearance Center RightsLink ${ }^{\circledR}$ service.

\section{CENOZOIC VOLCANISM, COLLISION, AND TECTONIC MODE SWITCHES}

Another focus of our research has been to refine our understanding of tectonic events that occurred during the Cenozoic - in particular, episodes of volcanism as well as periods of crustal shortening and extension associated with the long history of interaction between the Australia, Pacific, and Philippine Sea plates. We have paid particular attention to documenting cross-cutting relations within the field, as well as within hand-samples and thin sections. We have then obtained new biostratigraphic data and/or isotopic data to update the regional stratigraphy, understand the provenance of sediments and geological terranes, and where possible, to place upper and lower boundaries on the timing of episodes of magmatism and deformation. Several studies have focused on the northernmost margin of the Bird's Head Peninsula to document the timing of Cenozoic collision, volcanism, and the translation of crustal fragments along the major Sorong Fault Zone (Webb et al., 2019; Webb et al., In Review), while another study focused on unravelling episodes of shortening and extension that are recorded in the metamorphic rocks of the Wandamen Peninsula (northeastern section of the Bird's Neck) (White et al., 2018).

This new work shows that the Tamrau Block of the northernmost Bird's Head was deformed and metamorphosed during three distinct events - the first episode involved amphibolite facies metamorphism possibly during the Oligo-Miocene. The second episode involved magmatic intrusions and eruptions during the Middle Miocene. This episode of magmatism caused contact metamorphism of the older sequences. A later episode of crustal shortening is recorded by asymmetric folds and steeply-inclined reverse faults, together with a late MiocenePliocene unconformity $(\sim 10.5-4.5 \mathrm{Ma})$ which we proposed to mark the collision of part of an island arc (Tosem Block) to western New Guinea (Webb et al., 2019). We also proposed that this episode of collision caused the Tamrau Block to be translated westwards by $\sim 300 \mathrm{~km}$, so that its original position must have been closer to the Bird's Neck and Bird's Body regions rather than its current position in the northernmost Bird's Head Peninsula (Webb et al., 2019). These findings are complimentary to the work conducted on the metamorphic rocks of the Wandamen Peninsula, which record multiple episodes of crustal shortening and extension (i.e., tectonic mode 
switches) during the Miocene and Pliocene. Our systematic mapping of deformation fabrics combined with new geochronological and thermochronological data demonstrate that this region likely experienced east-west crustal extension between 6-5 Ma, followed by two phases of folding during east-west shortening between 5-3 Ma, and finally a phase of uplift and east-west oriented extension between 3-0 Ma (Figure 5) (White et al., 2018). These deformation episodes are also arguably recognizable on the regional sea-level curve shown in Figure 2.

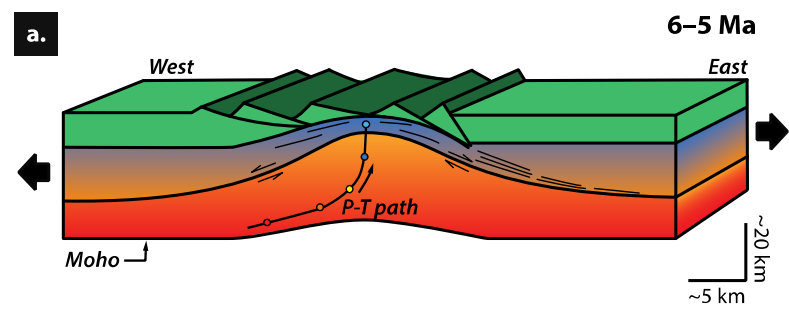

b.

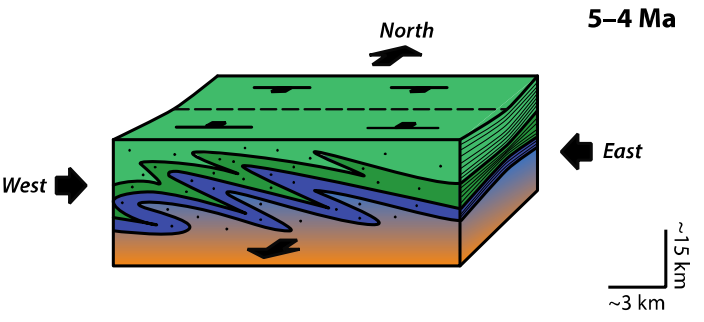

c.

4-3 Ma
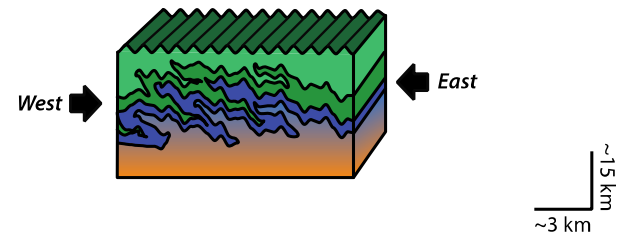

d. 3-0 Ma

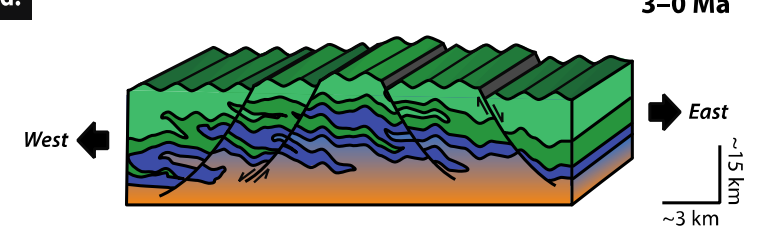

FIGURE 5. Schematic diagram showing the interpreted structural evolution of the Wandamen Peninsula (using an approximate scale as well as the modern-day orientation of the peninsula and structural data). Image taken from White et al., (2018) with permission from John Wiley and Sons using the Copyright Clearance Center RightsLink ${ }^{\circledR}$ service.

\section{CONCLUSIONS}

A focused effort to re-map, re-classify, and re-date rocks from Western New Guinea has led to new ideas and more detail about the tectonic history of this complex region. This includes newly developed paleogeographic maps and a better understanding of the details around the age of magmatism and episodes of shortening and extension. However, we acknowledge that there is still much to do, and we expect that in the near future the various information can be synthesized to update existing tectonic and paleogeographic reconstructions of New Guinea, eastern Indonesia, and Australia. 


\section{ACKNOWLEDGMENTS}

The work that is discussed here was largely supported by funding from a consortium of oil companies who sponsored the Southeast Asia Research Group (SEARG) between 2014 and 2017, together with additional internal research grants provided by the GeoQuEST Research Centre and Faculty of Science, Medicine and Health at the University of Wollongong. We thank Robert Hall for his support and advice associated with many of the papers that have been discussed here as well as our other various collaborators. Pak Joko Soesilo and the other ICEMINE conference coordinators for their invitation to attend the 2019 meeting, as well as for funding the travel costs of LW.

\section{REFERENCES}

1. V. Bailly, M. Pubellier, J. C. Ringenbach, J. de Sigoyer and F. Sapin, Lithos 113, 306-317 (2009).

2. G. M. Bladon, "Catalogue, appraisal, and significance of $K$-Ar isotopic ages determined for igneous and metamorphic rocks in Irian Jaya", Preliminary Report. Indonesia-Australia Geological Mapping Project (79 pp) (1988).

3. D. B. Dow, G. P. Robinson, U. Hartono, N. Ratman, "Geologic map of Irian Jaya”. Geological Research and Development Centre, Indonesian Ministry of Mines and Energy, Indonesia 1:1,000,000 (1986).

4. D. B. Dow, G. P. Robinson, U. Hartono, N. Ratman, "Geology of Irian Jaya: Preliminary Geological Report". Geological Research and Development Centre - Bureau of Mineral Resources, Canberra (1988).

5. J. Decker, F. Ferdian, A. Morton, M. Fanning, L.T. White, "New Geochronology Data from Eastern Indonesia - An Aid to Understanding Sedimentary Provenance in a Frontier Region". Indonesian Petroleum Association, Proceedings 41st Annual Convention, Jakarta, (2017)

6. D. P. Gold, L. T. White, I. Gunawan, M. K. BouDagher-Fadel, Marine and Petroleum Geology 86, 1133-1158 (2017)

7. W. Hamilton, "Tectonics of the Indonesian Region". Geological Survey Professional Paper 1078 (United States Government Printing Office, Washington, 1979)

8. K.C. Hill and R. Hall, "Mesozoic-Cenozoic evolution of Australia's New Guinea margin in a west Pacific context", in Special Paper 372: Evolution and Dynamics of the Australian Plate 372. pp. 265-290 (2003).

9. B.U. Haq and A. M. Al-Qahtani, GeoArabia 10,127-160 (2005).

10. B. M. Jost, M. Webb, L. T. White, Lithos 312-313, 223-243 (2018).

11. I. Metcalfe, Journal of Asian Earth Sciences 76, 195-213 (2013).

12. K. G. Miller, G. S. Mountain, J. D. Wright, J. V. Browning, Oceanography 24, 40-53 (2011).

13. R. D. Müller, M. Sdrolias, C. Gaina, B. Steinberger, C. Heine, Science 319, 1357-1362 (2008).

14. A. A. Pairault, R. Hall, C. F. Elders, Marine and Petroleum Geology, 20, 1141-1160 (2003).

15. P. E. Pieters, C. J. Pigram, D. S. Trail, D. B. Dow, N. Ratman, N., R. Sukamto, Bulletin of the Geological Research and Development Centre 8, 14-48 (1983).

16. A. Saputra, R. Hall, L. T. White, "Development of the Sorong Fault Zone North of Misool Eastern Indonesia" Indonesian Petroleum Association, Proceedings 38th Annual Convention, Jakarta, (2014).

17. J. W. Snedden, C. Liu, "A compilation of Phanerozoic sea-level change, coastal onlaps and recommended sequence designations" AAPG Search Discov. Article 40594 (2010).

18. W. A. Visser, J. J. Hermes, "Geological results of the exploration for oil in Netherlands New Guinea" Verhandelingen Koninklijk Nederlands Geologisch en Mijnbouwkundig Genootschap, Geologische Serie 20 (265pp) (1962).

19. M. Webb, L. T. White, Journal of Asian Earth Sciences 132, 58-74 (2016).

20. M. Webb, L. T. White, B. M. Jost, H. Tiranda, Journal of Asian Earth Sciences 179, 238-260 (2019).

21. M. Webb, L. T. White, B. M. Jost, H. Tiranda, M. BouDagher-Fadel. "The history of Cenozoic volcanism and collision in NW New Guinea - New insights into the tectonic evolution of the northernmost margin of the Australian Plate". Gondwana Research (in review).

22. L. T. White, R. Hall, I. Gunawan, B. Kohn. Tectonics 38, 26 pp, doi:10.1029/2018TC005177 (2018). 